\title{
PEMANFAATAN DAN PROSPEK PELEPAH BATANG PISANG KEPOK SEBAGAI BAHAN BAKU MEBEL
}

\author{
Oleh : \\ Fauziati $^{\top}$
}

\begin{abstract}
The research results have shown that the products made by the machine have relatively smaller of the coefficient of variance $(\mathrm{CV})$ than the products made by the crafters.

The $\mathrm{cv}$ of the thickness is a variation of data in the process of thickness measurement. The thickness $\mathrm{cv}$ of the sample made by the machine is $3,7 \%, 1,6 \%$; and $5,8 \%$ for the sample taken the outer layer of the stem (G1), from the middle layer of the stem (G2) and from the inner layer of the stem (G3) respectively. In addition, the thickness increase the variation of data goes up . It shows that the thickness is not even and the decrease of tensile strength of $G 4$ is $791,7 \mathrm{~N}$ / $89,7 \mathrm{~kg}$; G1 is 465,3 testing of all treatments $(G 1, G 2, G 3$ and G4) is good (3-4).
\end{abstract}

Keywords : layer of the stem, produce crafts raw material.

\section{PENDAHULUAN}

7 anaman pisang (Musa Paradisca) merupakan komoditi holtikultura yang cocok ditanam di Kalimantan Timur, dimana potensinya cukup besar rata-rata 42.904 ton pertahun dengan luas lahan sekitar $391.000 \mathrm{Ha}$ (Dinas Pertanian Tanaman Pangan Prop. Kaltim, 2005 ). Ada beberapa jenis tanaman pisang yang tumbuh di Kalimantan Timur diantaranya adalah pisang Ambon, pisang Mauli , pisang Batu, pisang Raja dan pisang Kepok dan yang paling banyak dibudidayakan oleh masyarakat adalah pisang Kepok.

Selama ini masih terbatas penggunaan bagian - bagian dari tanaman pisang tersebut oleh masyarakat setempat karena belum dikuasainya teknologi oleh kebanyakan petani maupun pengrajin.

Selain buah pisang yang dapat dinikmati langsung dalam bentuk buah segar bagian lain yang dapat dimanfaatkan sebagai bahan makanan adalah jantung pisang ,bonggol pisang dan yang tidak kalah pentingnya adalah batang pisang yaitu kulit pelepah batang pisang digunakan sebagai bahan baku furniture atau mebel.

Pohon pisang setelah berproduksi ( berbuah) dan dipetik kemudian pohonnya ditebang karena mati dan biasanya hanya dibuang disekitar tanaman pisang yang masih produksi dan ada kecenderungan membusuk dan akibatnya mengakibatkan disekitar tanaman menjadi kotor dan ada kesan menjadi tidak terawat.

Di KalimantanTimur saat ini terdapat 2 (dua) pengrajin mebel yang menggunakan bahan baku dari kulit pelepah batang pisang dan bahan bakunya diperoleh dari pulau Jawa ( Jawa Timur dan Jawa Tengah ) dan peminatnya cukup banyak baik lokal Kalimantan Timur maupun orang asing yang merupakan tenaga ekspert dari beberapa perusahaan asing yang mengagumi bahan bahan yang natural, dan produk mebel tersebut secara visual ada kemiripan dengan rotan. Bahan baku mebel yaitu pelepah batang pisang bisa dibuat dari jenis tanaman pisang apa saja.

Permasalahan yang dihadapi pengrajin saat ini adalah bahan baku dibeli dari Pulau Jawa ,sementara bahan baku kulit pelepah batang pisang tersebut cukup banyak di Kalimantan Timur . Sedangkan masalah teknis yang dihadapi pengrajin saat ini adalah bahan baku yang dibeli dari pulau Jawa kulit pelepah batang pisang apabila dianyam cenderung patah-patah karena ketebalannya tidak merata. Hal tersebut terjadi karena selama ini pengrajin mengerjakannya secara manual dengan jalan mengeringkan pelepah batang pisang yang masih basah ( kadar air nya $80-90 \%$ ) selama $7-10$ hari biasanya setelah kulit pelepah batang pisang kering dipisahkan dari seratnya dengan tangan , sehingga ada kecenderungan ketebalan permukaan kulit pelepah batang pisang menjadi tidak merata. 
Pada penelitian ini dicoba menggunakan alat pengolah kulit pelepah batang pisang, dengan jalan memisahkan kulit pelepah batang pisang dan seratnya dalam keadaan basah kemudian dikeringkan biasanya memerlukan waktu 2-3 hari.

Analisa parameter uji untuk penelitian ini meliputi kadar air pelepah basah dan setelah dikeringkan, ketebalan kulit dengan permukaan yang rata apabila dipintal tidak patah ,kekuatan tarik adalah beban maksimal yang dapat ditahan oleh suatu contoh uji sehingga contoh uji tersebut putus dan apabila dipintal tidak patah dan setelah dibuat mebel akan memberikan kekuatan terhadap beban ,ketahanan terhadap zat warna keringat (asam ,basa) dan apabila mebel digunakan tidak terjadi perubahan warna baik yang bersifat asam atau basa dan tahan gosok adalah tahan terhadap gesekan apabila mebel digunakan.

Diharapkan dengan menggunakan alat pemisah kulit pelepah pisang dan serat dapat menghasilkan ketebalan yang merata, sehingga pada saat dianyam tidak mudah patah.

\section{BAHAN DAN METODE}

\section{Peralatan}

Peralatan yang digunakan untuk memisahkan antara kulit pelepah batang pisang dengan seratnya adalah suatu peralatan dengan sistim belt berjalan menggunakan motor penggerak (mesin ) sebesar 1,5 HP, kemudian bagian ujung dari alat tersebut diletakkan pisau dengan sudut $22,5^{\circ}$. Diatas belt berjalan terdapat rol sebanyak 11 (sebelas) buah sepanjang belt berjalan tersebut yang fungsinya adalah sebagai penahan (beban ) dari pelepah batang pisang sehingga tidak bergeser pada saat mesin bergerak menuju pisau pembelah pelepah batang pisang untuk memisahkannya dengan serat batang pisang.

Diameter batang pisang berkisar antara $18-20 \mathrm{~cm}$, dan bagian dari batang pisang yang diambil diatas bonggol sampai dengan dibawah daun dengan panjang batang pisang kira-kira 2 (dua ) meter. Kemudian dipotong menjadi 2 bagian masing -masing 1 meter sesuai dengan panjang belt dan dibelah menjadi 2 bagian menjadi setengah lingkaran, sehingga lebar kulit pelepah batang menjadi $9-10 \mathrm{~cm}$ hal tersebut sesuai dengan panjang pisau.

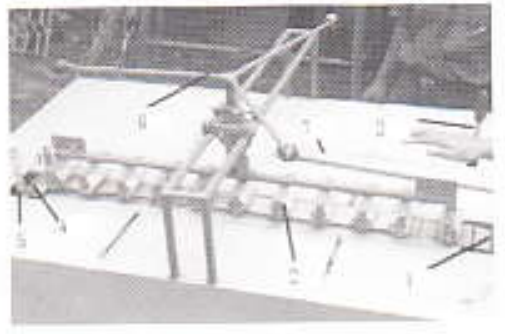

Keterangan gambar :

1.Belt berjalan

2.Rol penahan

3.Kopling

4. Pisau pembelah / penyerut

5.Pengatur posisi rol ( sesuai dengan ketebalan pelepah )

6.Pengatur posisi pisau.

Pelepah batang pisang

Gambar 1 : alat pemisah kulit pelepah batang pisang dengan serat

\section{Bahan}

Batang pisang yang digunakan sebagai bahan baku mebel berasal dari jenis pisang apapun baik pisang kepok, pisang batu dll. Pada penelitian ini khusus di gunakan jenis pohon pisang kepok, karena pohon pisang tersebut cukup potensial di Kalimantan Timur. Pelepah batang pisang yang digunakan sebagai bahan baku mebel adalah pada bagian luar (11-13 lembar), bagian tengah luar ( 11 lembar) dan bagian tengah dalam ( 11 lembar), sedangkan bagian paling dalam dari batang pisang tidak dapat digunakan karena sangat tipis.

Kulit pelepah batang pisang pada bagian luar berwarna hijau sampai ungu kemerahan dan keras. Biasanya setelah dikeringkan berwarna coklat dan sebagian coklat kemerahan. Khusus untuk kulit pelepah batang pisang bagian luar tersebut digunakan untuk mebel (kursi) yang memberikan beban seperti pada jog kursi, dan warna ungu kemerahan tersebut digunakan untuk variasi menambah nilai seni (art) dari produk yang dihasilkan.

Sedangkan pelepah bagian tengah yang terdiri dari 2 (dua) bagian yaitu bagian tengah luar berwarna kuning sampai putih dan biasanya setelah dikeringkan berwarna putih bersih dan lebih lemah dari pada bagaian luar. Bahan tersebut biasanya digunakan untuk mebel sofa (kursi malas) yang memerlukan keindahan dengan warna sama. Begitu pula untuk pelepah batang pisang bagian tengah dalam berwarna putih bersih digunakan untuk mebel yaitu seperangkat kursi dan 
meja yang memerlukan warna sama. Kulit batang pisang bagian tengah luar lebih liat, sehingga apabila dianyam tidak mudah patah.

\section{Prosedur Kerja :}

Satu pohon batang pisang dibagi 2 (dua ) bagian dengan ukuran masing-masing $\pm 1,0$ meter sesuai dengan panjang belt dengan lebar selebar pisau $\pm 9 \mathrm{~cm}$.

Setiap bagian pelepah batang pisang diletakkan diatas belt berjalan yang ditahan dengan rol pada saat pelepah menuju pisau ,maka pelepah tersebut akan terpisah menjadi 2 (dua ) bagian yaitu kulit bagian luar dan serat bagian dalam. Selanjutnya kulit pelepah batang pisang dan serat dikeringkan dibawah sinar matahari, bila sinar matahari maksimum maka diperlukan wąktu pengeringan \pm 2 hari dan apabila cuaca tidak mendukung maka kulit pelepah batang pisàng dimasukkan kedalam air mendidih \pm 10 menit yang apinya telah dimatikan kemudian ditiriskan selanjutnya dijemur dan diangin-anginkan.

Setelah kulit pelepah batang pisang dan bagian dalamnya kering kemudian dipintal dengan menggunakan alat pintal dimana bagian dalam sebagai bahan pengisi adalah serat batang pisang.

Parameter yang diamati adalah ketebalan dan Kadar air untuk pelepah batang pisang segar sebelum diolah adalah penting untuk mengetahui efektifitas kemampuan alat pengolah pelepah batang pisang yaitu memisahkan antara kulit dan seratnya sehingga waktu dikeringkan tidak terlalu lama 2-3 hari dan ketebalan merata, dibandingkan dengan yang diolah pengrajin tidak menggunakan alat dalam keadaan basah pelepah yang belum dipisahkan antara kulit dan seratnya dikeringkan memerlukan waktu yang lama yakni \pm 10 hari dan diperoleh ketebalan yang tidak merata. Parameter uji setelah kulit pelepah batang pisang diolah dan dikeringkan ( hasil penelitian ) dan dibandingkan dengan pengrajin meliputi kadar air ,ketebalan kekuatan tarik dan ketahanan terhadap zat warna baik Cara uji parameter tersebut menggunakan SNI untuk parameter ketebalan adalah SNI 08-0274-99, Moisture content (kadar air) SNI 08 -0263-89, kekuatan tarik SNI 08-0276-89, ketahanan zat warna asam dan basa adalah SNI 08-0287-96 dan tahan gosok SNI 08-0288-89.

\section{HASIL DAN PEMBAHASAN}

Batang pisang yang digunakan sebagai sampel adalah sebanyak 5 (lima) batang pisang sepanjang 2 meter, kemudian dipotong menjadi 2 bagian masing-masing menjadi 1 meter. Tiaptiap 1 meter batang pisang tersebut terdapat \pm 35 lembar pelepah batang pisang dan seratnya ,terdiri dari pelepah pada lembar pertama atau bagian paling luar terdiri dari 11-13 lembar berwarna hijau atau ungu kehitaman biasanya setelah dikeringkan pelepah tersebut sangat keras. Adakalanya digunakan sebagai sebagai bahan baku mebel dengan fungsi untuk menambah daya seni dan kekuatan. Lapisan kulit pelepah batang pisang bagian tengah luar berwarna hijau sampai kuning terdiri dari 11 lembar, mempunyai keuletan ( kekuatan ) yang tinggi dan setelah dikeringkan tidak terlalu keras, biasanya digunakan untuk mebel yang mempunyai warna sama. Lapisan kulit pelepah batang pisang bagian tengah dalam berwarna putih kekuningan terdiri dari 11 lembar, biasanya kulit pelepah batang pisang tersebut setelah kering agak lunak dan mempunyai warna putih dan cerah. Sedangkan pelepah yang tipis terdapat pada bagian dalam berwarna putih bersih dan bagian ini tidak dapat digunakan sebagai bahan baku kerajinan. Parameter uji yang dilakukan untuk pelepah batang pisang segar adalah meliputi : tebal pelepah dan kadar air hal ini diperlukan untuk mengetahui ketebalan awal dari pelepah batang pisang yang masih mengandung serat dan kadar air untuk mengetahui efektifitas pengeringan pelepah batang pisang setelah diolah dengan menggunakan alat pemisah kulit dan serat. Dibandingkan dengan yang dilakukan oleh pengrajin tanpa dipisahkan dulu antara pelepah dengan serat sehingga pada waktu dikeringkan memerlukan waktu lama \pm 10 hari , sedangkan setelah dipisahkan antara kulit pelepah dengan serat dikeringkan memerlukan waktu \pm 2 - 3 hari. Tebal awal dari pelepah batang pisang segar (sebelum diolah) ditunjukkan pada tabel $1 \mathrm{Hasil}$ analisa kulit pelepah batang pisang segar sebelum diolah seperti $G_{1}$ sebesar $4,35 \mathrm{~mm} ; G_{2}$ sebesar $4,36 \mathrm{~mm}$ dan $\mathrm{G} 3$ sebesar $3,93 \mathrm{~mm}$, dan setelah 
diolah ( tabel 2 ) masing-masing 1,47; 1,98 dan 1,5 sedangkan kadar air dengan perubahan yang cukup signifikan yakni sebelum diolah (tabel 1 ) G1 $91,90 \%, G 291,94 \%$ dan G3 91,98 \% dan setelah diolah terjadi perubahan yang signifikan yaitu G1 12,1\%; G2 12,1\% dan G3 12,5\%.

Hasil analisis kulit pelepah batang pisang segar sebelum diolah dan hasil analisis parameter uji untuk kulit pelepah batang pisang hasil penelitian dari pengrajin dapat dilihat pada tabel 1 dan 2 berikut:

Tabel 1. Hasil Analisis Kulit Pelepah Batang Pisang Segar Sebelum Diolah

\begin{tabular}{|l|l|c|c|c|c|}
\hline \multirow{2}{*}{ No } & \multicolumn{1}{|c|}{ Jenis Uji } & \multicolumn{3}{|c|}{ Hasil Uji } & \multirow{2}{*}{ Cara Uji } \\
\cline { 2 - 5 } & Kode Contoh & G1 & G2 & G3 & \\
\hline 1. & Tebal, mm & 4,35 & 4,36 & 3,93 & SNI. 08-0274-99 \\
2. & Kadar Air (\%) & 91,90 & 91,94 & 91,98 & SNI. 08-0263-89 \\
\hline
\end{tabular}

\section{Keterangan :}

Setiap contoh Uji merupakan hasil rata-rata dari 10 (sepuluh) kali pengamatan

G1 $=$ Kulit pelepah batang pisang pada bagian luar

G2= Kulit pelepah batang pisang pada bagian tengah luar

G3= Kulit pelepah batang pisang pada bagian tengah dalam

Tabel 2. Hasil Analisis Parameter Uji Untuk Kulit Pelepah Batang Pisang Hasil Penelitian Dan Dari Pengrajin

\begin{tabular}{|c|c|c|c|c|c|c|}
\hline \multirow{2}{*}{ No } & \multirow{2}{*}{ PARAMETER } & \multicolumn{4}{|c|}{ Hasil Uji } & \multirow{2}{*}{ Cara Uji } \\
\hline & & G1 & G2 & G3 & G4 & \\
\hline 1. & $\begin{array}{l}\text { Tebal, mm } \\
\text { cv } \%\end{array}$ & $\begin{array}{l}1,47 \\
3,7\end{array}$ & $\begin{array}{l}1,98 \\
1,6\end{array}$ & $\begin{array}{l}1.5 \\
5.8\end{array}$ & $\begin{array}{c}2,86 \\
7,1\end{array}$ & SNI 08-0274-99 \\
\hline 2. & $\begin{array}{l}\text { Kekuatan tarik } / 2,5 \mathrm{~cm} \\
\mathrm{~N} \mathrm{~kg}\end{array}$ & $\begin{array}{c}965,3 \\
98,4\end{array}$ & $\begin{array}{l}1238,0 \\
126,2\end{array}$ & $\begin{array}{c}1232,1 \\
125,6\end{array}$ & $\begin{array}{c}791,7 \\
89,7\end{array}$ & $\begin{array}{l}\text { SNI. 08-0276-89 } \\
\text { Kec.00 mm/ menit } \\
\text { beban } 200 \mathrm{~kg} \text { jarak } \\
\text { jepit } 75 \mathrm{~mm} / \text { menit }\end{array}$ \\
\hline 3. & Moisture Content (MC) \% & 12,1 & 12.1 & 12.5 & 12.65 & SNI. 08-0263-89 \\
\hline 4. & Moisture regain (MR) & 13,8 & 13,8 & 14,4 & 14,0 & SNI, 08-0263-89 \\
\hline 5. & $\begin{array}{l}\text { Ketahanan Zat Warna } \\
\text { A. Keringat } \\
\text { 1. Asam } \\
\text { - perubahan Warna } \\
\text { - Penodaan Pada asetat } \\
\text { - Penodaan pada wol } \\
\text { 2. Basa } \\
\text { - Perubahan Warna } \\
\text { - Penodaan Pada Asetat } \\
\text { - Penodaan Pada Wol } \\
\text { B. Gosok } \\
\text { 1. Kering } \\
\text { 2. Basah }\end{array}$ & $\begin{array}{c}4-5 \\
4 \\
4 \\
\\
4-5 \\
4-5 \\
4\end{array}$ & $\begin{array}{c}3-4 \\
3 \\
3-4 \\
\\
3-4 \\
4 \\
3-4\end{array}$ & $\begin{array}{l}4 \\
4 \\
4\end{array}$ & $\begin{array}{c}4 \\
4-5 \\
4\end{array}$ & SNI. 08-0288-89 \\
\hline & Contoh & & & & & \\
\hline
\end{tabular}

Sumber : Laboratorium Balai Besar Tekstil Bandung, 2005

Keterangan :

G4= Contoh Kulit pelepah batang pisang dari pengrajin

$5=$ Sangat baik $3-4=$ Baik $3=$ Cukup

$4=$ Baik $1=$ Sangat tidak baik2= Kurang 
Dari tabel 2, dapat ditunjukkan bahwa:

1. Ketebalan kulit pelepah batang pisang kering adalah:

a. Untuk G1 ketebalan sebesar $1,47 \mathrm{~mm}$ dan coefisien variasi (cv) sebesar $3,7 \%$.

b. Untuk $\mathrm{G} 2$ ketebalan sebesar 1,98 $\mathrm{mm}$ dan coefisien variasi (cv) sebesar 1,6\%.

c. Untuk G3 ketebalan sebesar $1,5 \mathrm{~mm}$ dan coefisien variasi (cv) sebesar $5,8 \%$.

d. Untuk G4 ketebalan sebesar $2,86 \mathrm{~mm}$ dan coefisien variasi (cv) sebesar $7,1 \%$.

G4 adalah contoh uji sebagai kontrol ketebalan kulit pelepah batang pisang kering.

Hasil uji ketebalan G1, G2, G3, dan G4 merupakan nilai rata- rata ( ) pengukuran atau pengujian dari sampel atau populasi. Masing - masing sampel sebanyak 5 kali pengukuran.

Dari hasil pengukuran ketebalan tersebut diatas menunjukkan bahwa semakin tinggi coefisien variasi (cv) yang merupakan variasi data dalam proses pengukuran ketebalan, semakin tinggi variasi data hasil ujinya. Hal tersebut dapat ditunjukkan dengan nilai simpang data (devisiasi standar) dari nilai rata-rata.

$$
S D(\text { devisiasi Standar })=\frac{\sqrt{\sum(X, \bar{X})^{2}}}{(n-1)}
$$

Semakin tinggi nilai SD ( standar devisiasi) berarti data dan sampel atau populasi nilai uji sangat beragam dan bervariasi.

Dari nilai standar devisiasi (SD), maka diperoleh nilai coefisiensi variasi.

$$
\mathrm{Cv}=\frac{\mathrm{SD}}{\overline{\mathrm{X}}} \times 100 \%
$$

Jadi dapat disimpulkan bahwa semakin besar cv, maka variasi data hasil uji untuk ketebalan kulit pelepah batang pisang semakin beragam (tinggi) atau dapat dikatakan pada setiap contoh uji mempunyai ketebalan yang tidak merata. Hal tersebut dapat ditunjukkan oleh contoh uji G4 (kulit pelepah batang pisang dari pengrajin), yang mempunyai nilai coefisien variasinya sebesar $7,1 \%$.

\section{Kekuatan tarik kulit pelepah pisang kering}

Kekuatan tarik adalah beban maksimal yang dapat ditahan oleh suatu contoh uji sehingga contoh uji tersebut putus.

a. Kekuatan tarik $\mathrm{G} 1$ sebesar $965,3 \mathrm{~N}(98,4 \mathrm{~kg})$

b. Kekuatan tarik $\mathrm{G} 2$ sebesar $1238,0 \mathrm{~N}(126,2 \mathrm{~kg})$

c. Kekuatan tarik G3 sebesar $1232,1 \mathrm{~N}(125,6 \mathrm{~kg})$

d. Kekuatan tarik G4 sebesar $791,7 \mathrm{~N}(80,7 \mathrm{~kg})$

Dari hasil uji kuat tarik kulit pelepah batang pisang menunjukkan bahwa G4 (kulit pelepah batang pisang dari pengrajin ) mempunyai kekuatan tarik yang paling kecil dibandingkan dengan kekuatan tarik kulit pelepah batang pisang G1, G2, dan G3. hal tersebut menunjukkan bahwa karena ketebalan dalam contoh uji tersebut tidak merata sehingga menyebabkan beban maksimal yang dapat ditahan oleh kulit pelepah batang pisang tersebut kecil sehingga mudah putus atau mudah rapuh dibandingkan dengan contoh uji yang lainnya yaitu G1, G2, dan G3.

3. Kadar air Moisture Content (MC)

a. Kadar air $\mathrm{G} 1$ sebesar $12,1 \%$

b. Kadar air G2 sebesar $12,1 \%$

c. Kadar air G3 sebesar $12,5 \%$

d. Kadar air G4 sebesar $12,65 \%$

Kadar air pelepah batang pisang segar rata-rata diatas $90 \%$ dan setelah dikeringkan menjadi rata- tara diatas $12 \%$, hal tersebut menunjukkan bahwa proses pengeringan dari pengrajin yang dilakukan secara manual yaitu dengan mengeringkan pelepah batang pisang segar (belum dipisahkan antara kulit dan serat) dengan menggunakan sinar matahari memerlukan waktu cukup lama yaitu diatas 7 (tujuh) hari apabila sinar matahari maksimal. 
Sedangkan proses pembuatan kulit pelepah batang pisang dengan alat diperlukan waktu 2-3 hari, atau bila cuaca tidak mendukung dapat dilakukan dengan merendamnya didalam air mendidih selama \pm 10 menit setelah apinya dimatikan kemudian dijemur.

1. Ketahanan zat warna terhadap keringat

a. Ketahanan Zatwarna terhadap keringat

1. Bersifatasam

Terjadi perubahan warna pada·kulit pelepah batang pisang G1 (4-5), G2 (3-4), G3 (4) dan G4 (4). Dari hasil tersebut dapat diketahui bahwa kulit pelepah batang pisang mempunyai ketahanan zat warna terhadap keringat yang bersifat asam rata-rata baik dan tidak mengalami perubahan warna. Hasil yang paling baik ketahanan zat warna terhadap keringat yang bersifat asam adalah $\mathrm{G} 1$ yaitu kulit pelepah batang pisang pada bagian luar.

2. Bersifat basa

Terjadi perubahan warna pada kulit pelepah batang pisang G1 (4-5), G2 (3-4), G3 (4) dan G4 (3-4). Dari hasil tresebut dapat diketahui bahwa kulit pelepah batang pisang mempunyai ketahanan zat warna terhadap keringat yang bersifat basa rata-rata baik dan tidak mengalami perubahan warna. Hasil yang paling baik ketahanan zat warna terhadap keringat yang bersifat basa adalah $\mathrm{G} 1$ yaitu kulit pelepah batang pisang pada bagian luar.

b. Ketahanan Zat warna terhadap gosokan

1. Gosokan kering

$$
\begin{aligned}
G 1 & =4-5 \\
\text { G2 } & =3-4 \\
\text { G3 } & =4 \\
\text { G4 } & =4
\end{aligned}
$$

Dari hasil tersebut diatas dapat diketahui bahwa ketahanan zat warna kulit pelepah batang pisang terhadap gosokan kering rata-rata baik dan tidak mengalami perubahan warna. Hasil yang paling baik ketahanan zat warna terhadap gosokan kering adalah $\mathrm{G} 1$ yaitu kulit pelepah batang pisang pada bagian luar.

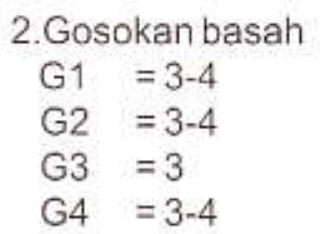

Dari hasil tersebut diatas dapat diketahui bahwa ketahanan zat warna kulit pelepah batang pisang terhadap gosokan basah rata-rata baik dan tidak mengalami perubahan warna. Hasil yang paling rendah (cukup) adalah $\mathrm{G} 3$ yaitu kulit pelepah batang pisang pada bagian tengah dalam.

\section{KESIMPULAN}

1. Kulit pelepah batang pisang sebagai bahan baku mebel dapat dibuat dari berbagai jenis pisang termasuk pisang kepok, karena disamping jenis pisang tersebut paling dominan tumbuh di Kaltim, khusus kulit pelepah bagian luar ( G1) memberikan warna kemerahan dan keras biasanya digunakan pengrajin sebagai bahan mebel yang memberikan corak / dekorasi. Sedangkan hasil pelepah bagian tengah luar berwarna putih kekuningan ( G2 ) diperuntukkan untuk mebel dengan warna sama.

2. Contoh uji kulit pelepah batang pisang G4 (sebagai kontrol uji) mempunyai coefisien variasi (cv) paling besar diantara contoh uji lainnya sebesar $(7,1 \%)$ yang menunjukkan bahwa semakin besar coefisien variasi (cv) ketebalan, maka semakin tinggi variasi data hasil ujinya 
berarti contoh uji tersebut mempunyai ketebalan tidak merata dan cenderung mudah patah pada saat diayam.

Hasil uji kuat tarik menunjukkan bahwa contoh uji G4 paling rendah $(792,7 \mathrm{~N} / 80,7 \mathrm{~kg})$, hal tersebut terjadi karena dalam satu contoh kulit pelepah batang pisang mempunyai ketebalan yang tidak sama mengakibatkan kuat tarik rendah dan pada waktu dianyam cenderung mudah patah / rapuh.

3. Pembuatan kulit pelepah batang pisang dengan menggunakan alat / mesin pengolah lebih efisien dari pada dibuat secara manual karena:

a. Pelepah batang pisang segar mempunyai kadar air cukup tinggi $\pm 90 \%$, sehingga dengan memisahkan kulit pelepah dengan serat bagian dalam dengan alat / mesin sebelum dijemur adalah memperpendek waktu pengeringan dari 10 hari menjadi $2-3$ hari.

b. Menghasilkan produk ketebalan merata dan kuat tarik yang lebih besar sehingga tidak mudah putus / patah pada waktu dianyam dan cenderung menghasilkan produk dengan kapasitas lebih besar dari pada manual. Kapasitas alat dalam 1 jam menghasilkan 210 pelepah batang pisang ( 15 batang pisang per hari ), dan untuk pelepah batang pisang kering dihasilkan $37,5 \mathrm{~kg}$ per hari, sedangkan secara manual dihasilkan rata-rata $10 \%$ dari pada menggunakan alat karena proses secara manual sangat tergantung dengan sinar mata hari (memerlukan waktu \pm 10 hari).

4. Uji ketahanan zat warna terhadap keringat dan uji gosok semua contoh uji G1, G2, G3 dan G4 menghasilkan hasil uji rata-rata baik (3-4). 


\section{DAFTAR PUSTAKA}

Anonim. 2005. Laporan Hasil Pertanian Tanaman Pangan. Propinsi Kalimantan Timur.

Anonim. 2000. Penelitian Modifikasi Produktif Mesin Dekortikator untuk Serat Abaca. BPPI, Yogyakarta.

Cahyono, Bambang. 1995. Pisang Budidaya dan Analisis Usaha Tani. Kanisius, Yogyakarta.

Harun, Wauran. 1999. Prospek dan Manfaat Serat Pisang Abaca (Musa Textilesi Nee). Meta Abaca Indonesia, Bandung.

Hilman, Imam...(at al). 2001. Budidaya dan Prospek Pengembangan Abaca. Penebar Swadaya. Jakarta.

Kheyne. 1987. Tumbuhan Berguna Iridonesia I. Litbang Kehutanan, Jakarta.

Ola, A Luther...(at.al). 2001. Pemasarakatan Pengolahan Serat Abaca. Buletin Komunikasi No.213 Baristand Indag, Menado.

Standar Nasional Indonesia ( SNI 08-0276-89 ). Cara Uji Kekuatan Tarik.

Standar Nasional Indonesia (SNI 08-0263-89), Cara Uji Moisture Content (MC).

Standar Nasional Indonesia ( SNI 08-0288-89). Cara Uji Ketahanan Zat Warna Terhadap Gosok Kering/Basah.

Standar Nasional Indonesia ( SN1 08-0287-96). Cara Uji Ketahanan Terhadap Zat Warna Asam / Basa.

Standar Nasional Indonesia ( SNI 08-0274-99), Cara Uji Ketebalan. 